\title{
Planning's Contradicting Genius within the Twilight against the Empty Night
}

\section{Michael Gunder}

Just as men [sic] will want to stave off contradiction as much as possible in life, they seek an equal degree of comfort in science by decreeing as axiomatic that contradiction could not be real. ... Only contradiction drives us - indeed, forces us - to action. Contradiction is in fact the venom of all life, and all vital motion is nothing but the attempt to overcome this poisoning (von Schelling, 1997 [1813]: 124).

Most planners consider their profession to be primarily concerned with the aims of modern enlightenment. Arguably, the enlightenment is the promotion of a spirit of progress resolutely seeking a superior world, a better future of light and purity for the collective good. The definition of better and good is open to contention, and, of course, herein lies the rub. In attempting to create, at least the appearance of, a level playing field of fairness as to who defines the good, planning generally advocates a set of core values supportive of equity, democratic method and social justice. Explicit forces seldom overwhelm these norms of fair process in most modern democracies. However, they are often overcome when confronted by subtle, and frequently unquestioned beliefs, or sometimes even overt authoritative rationalities, which seek to advance predispositions disproportionately supportive of the principles of wealth maximisation and its concentration, not to mention power, in our, now globalised, capitalistic system.

When planning does fall short in applying this distributional 'goodness', or at least the appearance of fairness, many would consider that planning is no longer an agent of enlightenment. Some authors consider this to be planning's 'dark side', a term initially deployed by Oren Yiftachel (1995) and Bent Flyvbjerg (1995) in quite dissimilar circumstances. Yiftachel's use of the concept 'dark side' was as part of a title for an empirically based case study, illustrating how planning had been unashamedly deployed overtly by the Israeli State as a mechanism of tribal control, land alienation and displacement of Israeli Arabs.

Flyvbjerg's deployment of the term was as part of a broader critique of planning theory, which Flyvbjerg argued to be synonymous with modernity's wider inclination towards normative idealism. This is the propensity of modernity's orthodox discourses of social science, and related 'progressive' disciplines, including planning, to see only what is desirable, as if one lived in an ideal and perfect 
social reality, devoid of contradiction, meanwhile unashamedly failing to notice what is actually occurring.

In other words, modernity's propensity is a desire for a fantasy of perfection and light - the perfect city shining in the light of perfect structures inhabited by the lightness of being provided by perfect angelic people. This is a fantasy especially perpetrated by traditionalist theoreticians of modernist planning, in which only the desired enlightened side is privileged, theorised and observed. The imperfect, dark side that constitutes a less coveted social reality of blemish and strife, is largely empirically overlooked. This agonistic reality is, Flyvbjerg argues, the real rationality, or realrationalität, of the genuinely grounded world constituted by the imperfections of human striving, disagreement, desire and real-politics. It is an actuality of the Heideggerian 'being in the world', which Lacanians would suggest we desire to block out and, inauthentically, obscure with fantasies of ideological justification and wish-fulfilment. This allows us to preserve our desired delusions of a preferred genius - a spirit - that presents a world of sanctuary and certitude, not to mention a progression to an even better place on earth, even if this illusionary construct of social reality may be somewhat more appropriately predicated on a desire for enlightenment's precursor; ie. the baroque, which sought the creation of a taste, illusion or simulation of heaven on earth, rather than a materialisation of the real thing.

This delusion of solidity and safety, not to mention the dream, if not the fulfilment, of the creation of heaven on earth, is consistent with another everyday fantasy of modernist social reality, a fantasy unequivocally facilitated by planning's normative desire and advocacy for fairness. This is the fallacy that the state (in place of any former God) has concern and cares for us, provided we act responsibly in our duties to the state as good citizens. In Lacanian parlance, we are desired, protected, and even loved by an abstract 'big Other' that in its totality represents a fair social order. Yet, Lacan suggests that this big Other does not exist, rather it is merely a desired illusion (2006: 688). Further, it is an illusion perhaps believed and sought after most devotedly when society is being particularly unfair. For the very notion of the modern, its essence or central spirit, is perhaps the resultant aggregate product of our desired fantasies and their mandatory prerequisite not to challenge, or examine too finely, the cracks of contradiction in our beguiling dreams and ideals.

Accordingly, a dark side appraisal of our ideologically shaped reality may provide a helpful traversing of our fantasy constructs. It may be an intrinsically anti-modern intrusion for interrogating the outcomes of planning and other, more diverse, disclosures of the cultural and hegemonic movements that shape our public policies and actions. Yet, theorising issues within the context of a light/dark dichotomy creates its own problematic. The traditional spirit of modernity, as well as other conventional forms of western thinking, are placed, or located, under the inexorable power of binary reason, an underlying logic that Ed Soja refers to, after Derrida, as the "the terrorism of the either/or" (Soja, 2003: 271). Moreover, planning, and its related modernist disciplines, is seldom black or white in its agency. Planning rarely attains absolute fairness. Yet, similarly, it is seldom totally deceitful and discriminatory, at least within regimes that attempt to provide, at a minimum, the appearance of democratic rights for all citizens (perhaps in contrast to Yiftachel's Israeli planning appararti). 
While perhaps a bane to some, a core role of planning is to supply an aspect of society's paternal figure of authority and regulation, one that says: "No, you are not permitted to do that in this environment!" This regulatory function actually helps constitute our symbolically constructed culture and society. Most consider this regulation a societal good, if applied with fairness towards an acceptable end. Yet, as this seeming fairness or acceptable goal deteriorates towards what may be perceived by many as tyranny, planning, at a certain point, stops constituting a common good and develops into a specific blight. Further, the point of change from being a beneficial remedy to a toxic affliction is usually undecidable, ambiguous, and generally dependent on one's specific individual perspective and aims - be it those of developer, architect, or affected party (Derrida, 1981: 125).

Fundamentally, the light/dark duality only favours the achievement of perfectly impossible ideals. This idealised transcendental perfection is beyond what is achievable by human knowledge, or even knowable by experience. The attainment of any transcendentalidealisimpossible, by definition-indeed, atruecontradiction. To suppose otherwise is, innately, a utopian dream of modernity, or some other similar faith. Lacan suggests we have to acknowledge that our ideals will always come up short; they will always lack completeness and, even when the truth about our ideals is forthcoming, it may not be beneficial (2004: 15). Fundamentally, our ideals are so lacking in completeness that, over time, many turn out to be the cause of their initial decline and eventual obscurity. To paraphrase Lacan, with a touch of Deleuze, we simply overthrow the mastery of one transcendental ideal to replace it with the mastery of another, perpetuating a new void of lack, undecidability, contradiction and eventual dissatisfaction (129).

I suggest that the modern human disciplines, including planning, which, on the whole, materialised as artefacts of modernity's constant search for knowledge to contribute to the production of some better enlightened world, should not be considered as spirits that reside in either the light or dark: rather they should always be considered to reside somewhere in between. Planning resides in perpetual twilight, for planning's actual spirit of place - its specific genius loci - dwells somewhere between that of the empty darkness constituting the night of the world, and the divine light of our desires. Planning and modernity's other human practices of collective action are grey arts of chiaroscuro that take place in a shadowy reality of particularity and ambiguity (after Hillier, 2002: 17). This is a social reality where our practices, norms and ideals are imperfect, lacking and incomplete, consistent with the imperfection which constitutes the human condition of inherent contradiction. Here, perhaps, one task of academic critique is to expose these absences and tackle the illusions we form to cloak this emptiness. 


\section{References}

Derrida, J. (1981). Dissemination (B. Johnson, Trans.). Chicago: The University of Chicago Press.

Flyvbjerg, B. (1995). The Dark Side of Planning: Rationality and Realrationalität. In S. Mandelbaum, L. Mazza and R. Burchell (Eds.), Explorations in planning theory (pp. 383-394). New Brunswick, New Jersey: Rutgers Press.

Hillier, J. (2002). Shadows of power. London: Routledge.

Lacan, J. (2004). The seminar of Jacques Lacan, Book XVII, The other side of psychoanalysis: 1969-1970 (R. Grigg. Trans.). Photocopy of translator's manuscript.

Lacan, J. (2006). Ecrits: The first complete edition in English (B. Fink. Trans., in collaboration with H. Fink and R. Grigg). London: W. W. Norton.

Soja, E. (2003). Writing the City Spatially. City 7(3), 269-280.

von Schelling, F. (1997 [1813]). Ages of the world (J. Norman. Trans.). In S. Žižek and F. von Schelling The abyss of freedom/Ages of the world (pp. 103-182). Ann Arbor: University of Michigan Press.

Yiftachel, O. (1995). The Dark Side of Modernism: Planning as Control of an Ethnic Minority. In S. Watson and K. Gibson (Eds.), Postmodern cities and spaces (pp. 216-242). Oxford: Blackwell. 